\title{
Purification, $\boldsymbol{N}$-terminal amino acid sequence and properties of hydroxymethylbilane synthase (porphobilinogen deaminase) from Escherichia coli
}

\author{
Graham J. HART, ${ }^{*}$ Christopher ABELL and Alan R. BATTERSBY \\ University Chemical Laboratory, Lensfield Road, Cambridge CB2 1EW, U.K.
}

Hydroxymethylbilane synthase (porphobilinogen deaminase) was purified to apparent homogeneity from Escherichia coli. The enzyme is a monomer of $M_{\mathrm{r}}$ approx. 40000 . The $K_{\mathrm{m}}$ for porphobilinogen and relative $V_{\max }$. values have been obtained at various $\mathrm{pH}$ values over the range $6.2-8.8$, enabling $\mathrm{p} K$ values for ionizable groups important for activity to be determined. The $N$-terminal amino acid sequence is presented.

\section{INTRODUCTION}

Hydroxymethylbilane synthase, EC 4.3.1.8 [usually called 'porphobilinogen (PBG) deaminase'], together with uroporphyrinogen III synthase (EC 4.2.1.75), catalyse the transformation of PBG into uroporphyrinogen III (Battersby et al., 1980). This macrocycle is a precursor for a family of pigments including haem, chlorophyll and vitamin B-12. Some of the properties of PBG deaminases from a number of sources have been investigated (Davies \& Neuberger, 1973; Jordan \& Shemin, 1973; Higuchi \& Bogorad, 1975; Anderson \& Desnick, 1980; Shioi et al., 1980; Williams et al., 1981; Battersby et al., 1983a,b; Hart et al., 1984; Williams, 1984), but many potentially important studies are restricted by the small amounts of enzyme that can be conveniently purified. Thus studies are in progress to clone the PBG deaminase gene of Escherichia coli. We report here a purification of the enzyme, its $N$-terminal amino acid sequence and some of its properties.

\section{EXPERIMENTAL}

Bistris, Tris (Trizma grade), aprotinin, benzamidine hydrochloride, pepstatin, phenylmethanesulphonyl fluoride, dithiothreitol, bovine serum albumin, ovalbumin, carbonic anhydrase and cytochrome $c$ were from Sigma Chemical Co., Poole, Dorset, U.K. Bactotryptone and bactopeptone were from Difco Laboratories, East Molesey, Surrey, U.K. Other chemicals were analyticalreagent grade whenever available, or the purest available grade, and were obtained from Fisons Chemicals, Loughborough, Leics., U.K., or BDH Chemicals, Poole, Dorset, U.K. Deionized distilled water was used throughout.

\section{Enzyme assays}

PBG deaminase activity was determined as described by Battersby et al. (1983a). Protein concentrations were determined by $A_{280}$ measurements, assuming an $A_{1 \% m}^{1 \%}$ value of 10 .

\section{Buffer solutions}

$\mathrm{pH}$ values for buffer solutions were adjusted at room temperature, irrespective of the temperature at which they were subsequently used.

\section{Spectra}

U.v.-visible absorption spectra were recorded on a Uvikon 810 recording spectrophotometer (Kontron Instruments).

\section{Organisms}

Two stains of $E$. coli, K12 and JA 200/pLC 41-4, were used. The latter was obtained from the $E$. coli Genetic Stock Centre, Department of Human Genetics, Yale University School of Medicine, New Haven, CT, U.S.A., and is a derivative of $\mathrm{K} 12$. This strain was found to produce approx. seven times the PBG deaminase activity produced by $\mathrm{K} 12$.

\section{Growth of $E$. coli}

$\mathrm{K} 12$ cells were grown at $37^{\circ} \mathrm{C}$ in medium of the following composition: glucose $(10 \mathrm{~g} / \mathrm{l}),\left(\mathrm{NH}_{4}\right)_{2} \mathrm{SO}_{4}$ $(2 \mathrm{~g} / \mathrm{l}), \mathrm{MgSO}_{4}(0.8 \mathrm{~g} / \mathrm{l})$ and $\mathrm{KH}_{2} \mathrm{PO}_{4}(10 \mathrm{~g} / \mathrm{l})$, adjusted to $\mathrm{pH} 7.1$ with $\mathrm{NaOH}$. Strain JA $200 / \mathrm{pLC} 41-4$ was grown in the above medium supplemented with bactotryptone $(1.6 \mathrm{~g} / \mathrm{l})$, bactoyeast extract $(1 \mathrm{~g} / \mathrm{l})$ and $\mathrm{NaCl}$ $(0.5 \mathrm{~g} / \mathrm{l})$. A $200 \mathrm{ml}$ portion of an overnight shake culture was used to inoculate 201 of growth medium in a 251 fermenter vessel. During growth, the suspension was stirred at $250 \mathrm{rev} . / \mathrm{min}$, sterile air was slowly bubbled into the medium, and the $\mathrm{pH}$ was maintained at 7.1 by automatic titration with $5 \mathrm{M}-\mathrm{NaOH}$. Cells were harvested after $24 \mathrm{~h}$ (while they were still in the exponential phase of growth) by using a Sharples continuous-flow centrifuge, were washed with $0.1 \mathrm{M}$-sodium phosphate buffer, $\mathrm{pH}$ 7.6, containing 0.1 mM-dithiothreitol, and, if not used immediately, were stored at $-18^{\circ} \mathrm{C}$. A typical 201 growth gave $65 \mathrm{~g}$ wet weight of cells.

\section{Purification of PBG deaminase}

All solutions used during the purification of the enzyme contained the following additions, unless

Abbreviations used: PBG, porphobilinogen; f.p.l.c., fast protein liquid chromatography.

* To whom correspondence and reprint requests should be addressed. 
Table 1. Purification of PBG deaminase from $65 \mathrm{~g}$ wet weight of $E$. coli $\mathrm{JA} 200 / \mathrm{pLC} 41-4$

\begin{tabular}{|c|c|c|c|c|c|c|}
\hline Step & $\begin{array}{l}\text { Volume } \\
\text { (ml) }\end{array}$ & $\begin{array}{l}\text { Activity } \\
\text { (units) }\end{array}$ & $\begin{array}{l}\text { Protein } \\
\text { (mg) }\end{array}$ & $\begin{array}{c}\text { Specific } \\
\text { activity } \\
\text { (units } / \mathrm{mg} \text { ) }\end{array}$ & $\begin{array}{l}\text { Yield } \\
(\%)\end{array}$ & $\begin{array}{l}\text { Purification } \\
\text { (fold) }\end{array}$ \\
\hline Initial extract & 130 & 45000 & 12500 & 3.6 & 100 & 1 \\
\hline After heat treatment & 116 & 42000 & 11630 & 3.6 & 93 & 1 \\
\hline $\begin{array}{l}\text { After }\left(\mathrm{NH}_{4}\right)_{2} \mathrm{SO}_{4} \text { precipitation, dialysis and } \\
\text { gel filtration }\end{array}$ & 162 & 36200 & 207 & 175 & 80 & 49 \\
\hline After Mono Q HR 10/10 f.p.l.c. at pH 8.5 & 16 & 23800 & 4.3 & 5530 & 53 & 1540 \\
\hline After Mono Q HR 5/5 f.p.l.c. at pH 6.0 & 2 & 9800 & 0.54 & 18100 & 22 & 5030 \\
\hline After Mono Q HR 5/5 f.p.l.c. at pH 8.3 & 1.7 & 3800 & 0.17 & 22300 & 8.5 & 6190 \\
\hline
\end{tabular}

otherwise stated: dithiothreitol $(0.1 \mathrm{~mm})$, EDTA $(0.6 \mathrm{mM})$, aprotinin $(1 \mathrm{mg} / \mathrm{l})$, benzamidine hydrochloride (1 mM), pepstatin $(1 \mathrm{mg} / 1)$, phenylmethanesulphonyl fluoride $(0.6 \mathrm{mM}$, previously dissolved in ethanol, $5 \mathrm{ml} / 1$ of final solution). When proteinase inhibitors were not included, large losses of activity and irreproducible behaviour were often observed during ion-exchange chromatography.

Operations were performed at $0-4{ }^{\circ} \mathrm{C}$, except for the f.p.l.c. steps, which were at ambient temperature (generally $12-16^{\circ} \mathrm{C}$ ), but fractions from these columns were collected on ice.

Washed cells (thawed if previously frozen) were resuspended in $0.1 \mathrm{M}$-sodium phosphate buffer, $\mathrm{pH} 8.0$ ( $2 \mathrm{ml} / \mathrm{g}$ wet wt. of cells) and sonicated in approx. $70 \mathrm{ml}$ batches by using a Dawe Soniprobe (type 7530A) operated at $7 \mathrm{~A}$ for $4 \times 1 \mathrm{~min}$ each batch. The supernatant liquid from centrifugation $(20000 \mathrm{~g}, 30 \mathrm{~min})$ was divided into approx. $20 \mathrm{ml}$ portions and heated in tubes $(1.6 \mathrm{~cm} \times 15 \mathrm{~cm})$ in a water bath at $55^{\circ} \mathrm{C}$ for $10 \mathrm{~min}$, and then cooled in ice. Precipitated protein was removed by centrifugation $(20000 \mathrm{~g}, 15 \mathrm{~min}) .\left(\mathrm{NH}_{4}\right)_{2} \mathrm{SO}_{4}(430 \mathrm{~g} / \mathrm{l})$ was added, and after $30 \mathrm{~min}$ the precipitate was collected by centrifugation $(20000 \mathrm{~g}, 15 \mathrm{~min})$, resuspended in a minimum volume of $15 \mathrm{~mm}$-Tris/ $\mathrm{HCl}$ buffer, $\mathrm{pH} \mathrm{8.5,} \mathrm{and}$ dialysed against the same buffer for $1.5-2 \mathrm{~h}$. Insoluble protein was removed by centrifugation $(40000 \mathrm{~g}, 10 \mathrm{~min})$ and the clear solution was fractionated on a column $(4.6 \mathrm{~cm} \times 112 \mathrm{~cm})$ of Sephadex G-75 equilibrated with the last-mentioned buffer. Fractions $(14 \mathrm{ml})$ were collected at a flow rate of $75 \mathrm{ml} / \mathrm{h}$. PBG deaminasecontaining fractions were pooled and applied to a Mono Q HR 10/10 column attached to a Pharmacia f.p.l.c. system. The column had previously been equilibrated with $15 \mathrm{~mm}$-Tris $/ \mathrm{HCl}, \mathrm{pH} 8.5$, and was eluted at $2 \mathrm{ml} / \mathrm{min}$ with a linear gradient of $40-250 \mathrm{mM}-\mathrm{NaCl}$ in the same buffer; the gradient volume was $210 \mathrm{ml}$. PBG deaminase was eluted in four to five $4 \mathrm{ml}$ fractions at a $\mathrm{NaCl}$ concentration of approx. $190 \mathrm{~mm}$. [On some occasions a small second peak of PBG deaminase activity was found to be eluted immediately after the main peak of enzyme activity. This peak, which contained approx. $15 \%$ of the activity of the main peak, is probably a PBG deaminase-PBG complex; such complexes have been found for PBG deaminases from human erythrocytes (Anderson \& Desnick, 1980) and Rhodopseudomonas spheroides (Berry et al., 1981). This minor peak has not been characterized.] Combined fractions were dialysed overnight against $15 \mathrm{~mm}-$ Bistris/ $\mathrm{HCl}, \mathrm{pH} 6.0$, and applied to a Mono Q HR 5/5 f.p.l.c. column equilibrated with the same buffer. This buffer, in conjunction with a $\mathrm{NaCl}$ gradient $(0-250 \mathrm{~mm}$ in $40 \mathrm{ml}$ ), was also used for elution at a flow rate of $1 \mathrm{ml} / \mathrm{min}$. PBG deaminase was eluted at approx. $180 \mathrm{~mm}-\mathrm{NaCl}$ and the combined fractions were dialysed against $15 \mathrm{~mm}-\mathrm{Tris} / \mathrm{HCl}, \mathrm{pH}$ 8.3. At this stage SDS/ polyacrylamide-gel electrophoresis showed the presence of three minor impurities. These were removed by further f.p.l.c. (Mono Q HR 5/5; 0-330 mM-NaCl in $15 \mathrm{~mm}$-Tris/ $\mathrm{HCl}, \mathrm{pH} 8.3 ; 35 \mathrm{ml}$ gradient at $1 \mathrm{ml} / \mathrm{min}$ ). PBG deaminase was eluted at a $\mathrm{NaCl}$ concentration of approx. $220 \mathrm{~mm}$. The final product was dialysed against appropriate buffers as required.

\section{$M_{\mathbf{r}}$ determination}

The $M_{\mathrm{r}}$ value for PBG deaminase was determined by

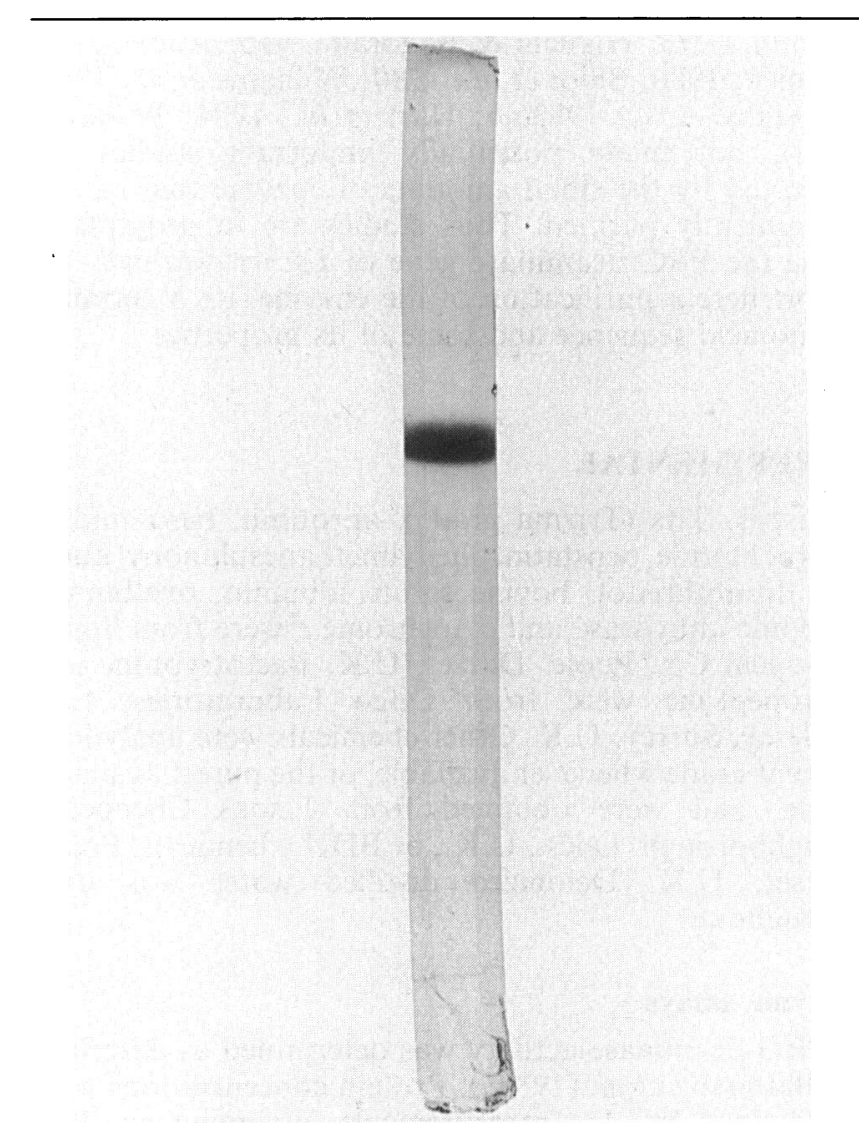

Fig. 1. Analysis of PBG deaminase from $E$. coli by SDS/ polyacrylamide-gel electrophoresis

Electrophoresis was performed as described in the text with $7.5 \mu \mathrm{g}$ of purified PBG deaminase. 


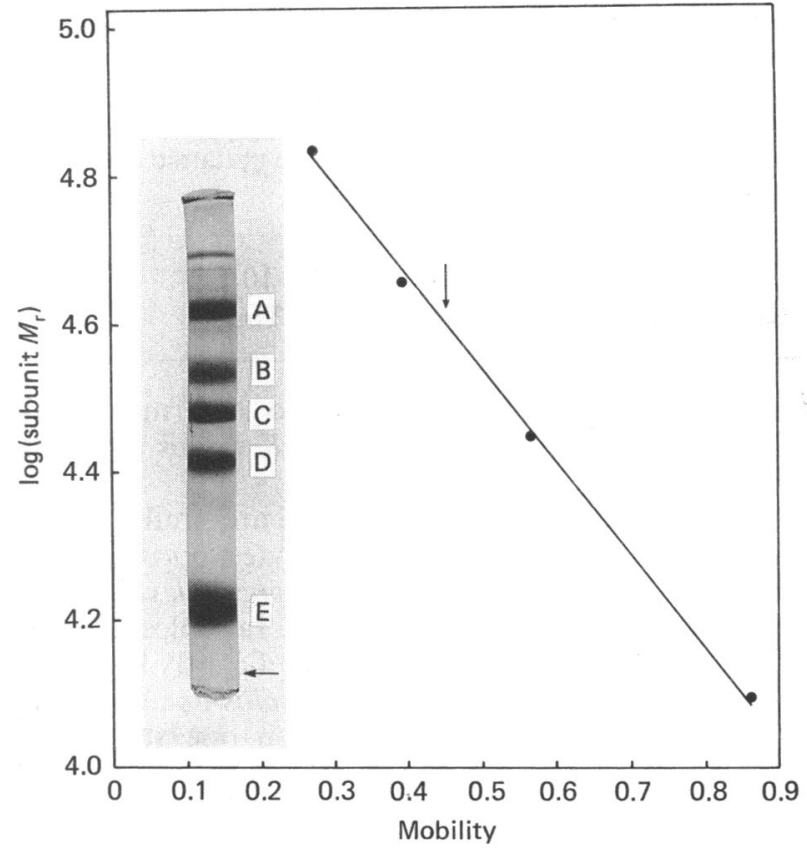

Fig. 2. Determination of minimum $M_{\mathrm{r}}$ for $P B G$ deaminase from $E$. coli by SDS/polyacrylamide-gel electrophoresis

The mobilities of the peptide chains relative to a Bromophenol Blue marker are plotted against log (subunit $M_{\mathrm{r}}$ ). The standards used are given above. The relative mobility of PBG deaminase is indicated by an arrow; this corresponds to an $M_{\mathrm{r}}$ of 39500 . Inset: SDS/polyacrylamide-gel electrophoresis was performed as described in the text. The protein bands indicated are: $\mathrm{A}$, bovine serum albumin $\left(M_{\mathrm{r}} 68000\right)$; B, ovalbumin $\left(M_{\mathrm{r}} 45000\right)$; C, PBG deaminase; D, carbonic anhydrase $\left(M_{\mathrm{r}} 29000\right) ; \mathrm{E}$, cytochrome $c\left(M_{\mathrm{r}}\right.$ 12400). The arrow indicates the mobility of the Bromophenol Blue marker.

gel filtration on a Superose 12 HR 10/30 f.p.l.c. column equilibrated with $0.05 \mathrm{M}$-sodium phosphate buffer, pH 7.0, containing $0.15 \mathrm{M}-\mathrm{NaCl}$, or with $0.1 \mathrm{M}-\mathrm{NaHCO}_{3}$, pH 8.2. The standards used (Sigma Chemical Co.) were bovine serum albumin, ovalbumin, carbonic anhydrase and cytochrome $c$. The void volume of the column was determined by using Blue Dextran. Samples were applied in a volume of $0.2 \mathrm{ml}$, the flow rate was $0.5 \mathrm{ml} / \mathrm{min}$ and the eluate was continuously monitored at $280 \mathrm{~nm}$.

The $M_{\mathrm{r}}$ value for PBG deaminase under denaturing conditions was determined by using SDS/polyacrylamide-gel electrophoresis by the method of Weber et al. (1972). The protein standards used were those listed above.

\section{Amino acid sequencing}

The $N$-terminal amino acid sequence was determined at the S.E.R.C. sequencing service, Department of Biochemistry, University of Aberdeen, Aberdeen, Scotland, U.K., by Professor J. Fothergill and Mr. B. Dunbar. Enzyme purified from both strains of E. coli was sequenced with identical results.

\section{RESULTS AND DISCUSSION}

Table 1 summarizes a typical purification. The final product, which showed only one band on SDS/ polyacrlamide-gel electrophoresis (Fig. 1), loses no more than $5 \%$ of its activity on storage on ice in $15 \mathrm{~mm}$ Bistris/ $\mathrm{HCl}$ buffer, $\mathrm{pH} 6.0$, or in $0.1 \mathrm{M}$-sodium phosphate buffer, $\mathrm{pH} 7.0$, over 28 days. The behaviour of the enzyme during the purification was identical for both strains of $E$. coli used. The final products were apparently identical as judged by $M_{\mathrm{r}}$ value, $K_{\mathrm{m}}$ for PBG and $N$-terminal amino acid sequence (see below).

The u.v.-visible absorption spectra of enzyme samples

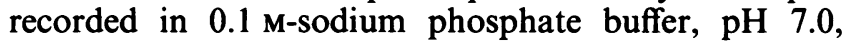
contaning EDTA $(0.6 \mathrm{mM})$ and dithiothreitol $(0.1 \mathrm{mM})$ as the only additions showed only one absorption maximum, at $276-278 \mathrm{~nm}$, with a small shoulder at $290-295 \mathrm{~nm}$; there was no absorbance above $320 \mathrm{~nm}$. There is thus no evidence for bound cofactors.

Gel-filtration experiments on a calibrated Superose 12 column indicated an $M_{\mathrm{r}}$ value in the range 34000-40000. The lower value was obtained when the column was run in $0.05 \mathrm{M}$-sodium phosphate buffer ( $\mathrm{pH} 7.0)$ / $0.15 \mathrm{M}-\mathrm{NaCl}$, the higher value when the column was run in $0.1 \mathrm{M}-\mathrm{NaHCO}_{3}$. SDS/polyacrylamide-gel-electrophoretic experiments, one of which is shown in Fig. 2, indicated a minimum $M_{\mathrm{r}}$ value of $39100 \pm 1600$ (mean\pm S.D. for five determinations). PBG deaminase from $E$. coli is clearly monomeric, and the enzyme is similar in size to those from human erythrocytes (Anderson \&

Table 2. Results from kinetic experiments at various pH values for PBG deaminase from $E$. coli

Assays were carried out at $37^{\circ} \mathrm{C}$ over a range of PBG concentrations in $0.2 \mathrm{M}$-sodium phosphate buffers (pH 6.2-8.0) or in $0.2 \mathrm{M}$-sodium pyrophosphate buffers (pH 8.0-8.8), and apparent values for $K_{\mathrm{m}}$ and $V_{\max }$. were obtained from plots of [PBG]/initial velocity against $\left[\mathrm{PBG}\right.$. Mean values of $V_{\mathbf{m a x}}^{\mathrm{app}}$. for each $\mathrm{pH}$ value are expressed relative to the mean value (assigned as 1.00 ) obtained at $\mathrm{pH} 7.4$.

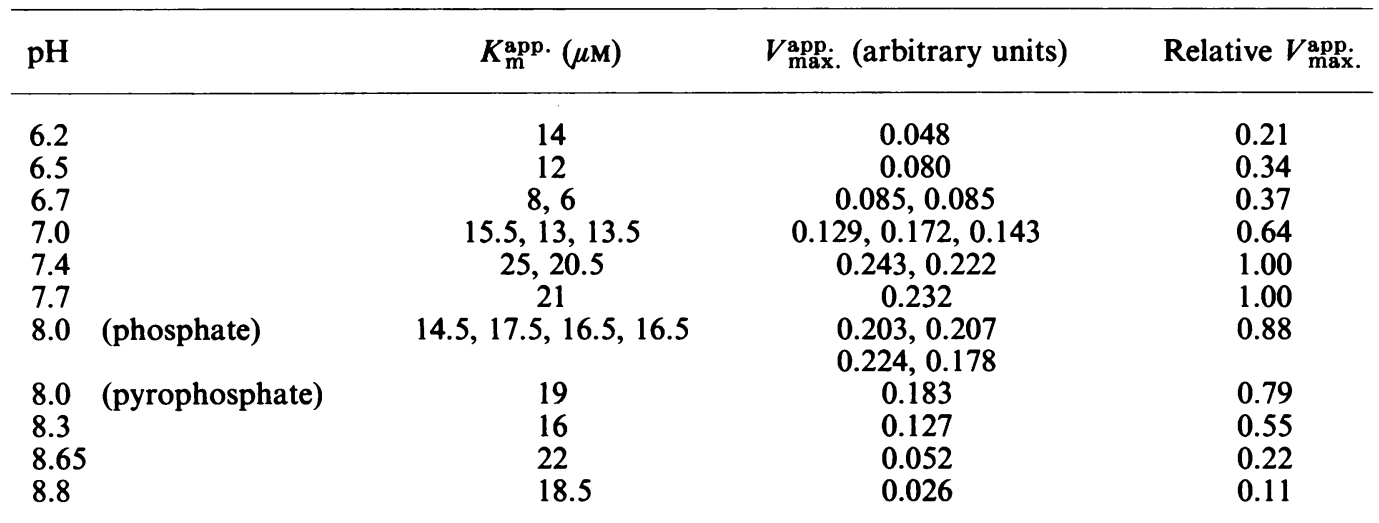



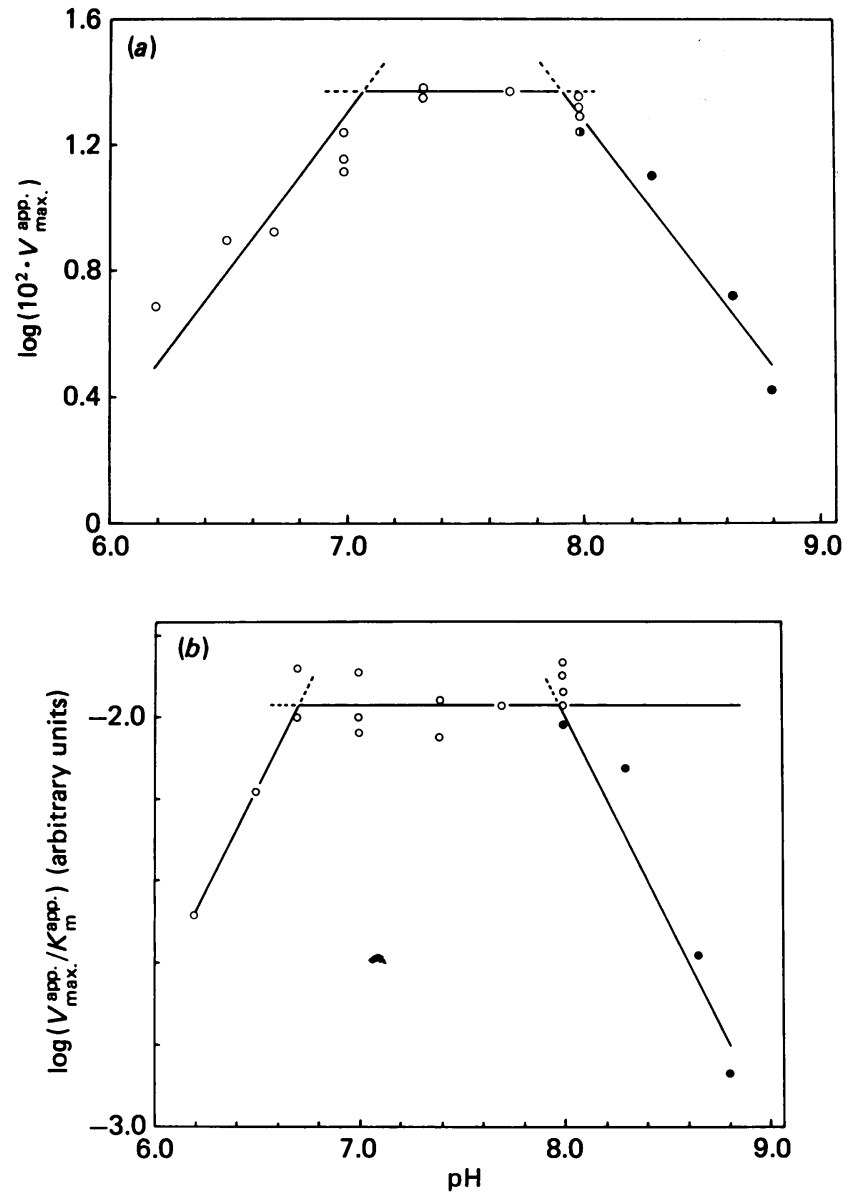

Fig. 3. Effect of pH on (a) $\log \left(V_{\text {app. }}^{\text {ap. }}\right)$ and (b) $\log \left(V_{\text {app. }}^{\text {app. }} /\right.$ $\left.K_{\mathrm{m}}^{\text {app. }}\right)$ for $\mathrm{PBG}$ deaminase from $E$. coli

Values for $V_{\max }^{\mathrm{app}}$. and $V_{\max }^{\mathrm{app}} . / K_{\mathrm{m}}^{\mathrm{app}}$. were obtained from plots of $[\mathrm{PBG}] /$ initial velocity against $[\mathrm{PBG}]$ made at several $\mathrm{pH}$ values in $0.2 \mathrm{M}$-sodium phosphate buffers $(O)$ or $0.2 \mathrm{M}$-sodium pyrophosphate buffers (O). Logarithms of the values obtained are plotted against $\mathrm{pH}$.

Desnick, 1980), spinach (Higuchi \& Bogorad, 1975), Rhodopseudomonas spheroides (Davies \& Neuberger, 1973; Jordan \& Shemin, 1973), Chlorella regularis (Shioi et al., 1980), rat spleen (Williams, 1984) and Euglena gracilis (Williams et al., 1981).

Kinetic experiments were made at several $\mathrm{pH}$ values and values for $V_{\max }^{\mathrm{app}}$. and $K_{\mathrm{m}}^{\mathrm{app}}$, obtained from plots (not shown) of [PBG]/initial velocity against $[\mathrm{PBG}]$, are given in Table 2. Plots of $\log \left(V_{\max }^{\mathrm{app}}\right)$, and $\log \left(V_{\max }^{\mathrm{app}} / K_{\mathrm{m}}^{\mathrm{app}}\right.$. against pH were then constructed (Fig. 3); the intersection points for the straight-line sections of the plots, which must have slopes of $+1,0$ and -1 , are the $\mathrm{pH}$ values corresponding to $\mathrm{p} K_{1}{ }^{\mathrm{ES}}, \mathrm{p} K_{2}{ }^{\mathrm{ES}}$ and $\mathrm{p} K_{1}{ }^{\mathrm{E}}$, $\mathrm{p}_{2}{ }_{2}{ }^{\mathrm{E}}$ respectively (see, e.g., Cornish-Bowden, 1979), where $\mathrm{pK}{ }^{\mathrm{ES}}$ values represent ionizations in enzymesubstrate complexes and $\mathrm{p} K^{\mathrm{E}}$ values represent ionizations in free enzyme. The values determined for $\mathrm{p} K_{1} \mathrm{ES}$, $\mathrm{p} K_{2}{ }^{\mathrm{ES}}, \mathrm{p} K_{1}{ }^{\mathrm{E}}$ and $\mathrm{p} K_{2}{ }^{\mathrm{E}}$ were 7.07, 7.92, 6.70 and 7.98 [cf. those determined for PBG deaminase from Euglena gracilis by Williams et al. (1981), which were 6.1, 8.9, < 5 and 8.2 respectively]. It is noteworthy that binding of PBG to $E$. coli $\mathrm{PBG}$ deaminase has virtually no effect on $\mathrm{p} K_{2}$, but $\mathrm{p} K_{1}$ is increased by $0.37 \mathrm{pH}$ unit, presumably reflecting a substrate-induced conformational change.
Table 3. $N$-Terminal amino acid sequence for PBG deaminase from $E$. coli

One preparation gave small amounts of glycine, alanine or methionine at position 1 in addition to glutamic acid. The remaining sequence was identical.

$\begin{array}{ccc}1 & 5 & 10\end{array}$

Glu-Leu-Asp-Asn-Val-Leu-Arg-Ile-Ala-Thr-

Further work will be necessary to determine which critical ionizations give rise to the $\mathrm{p} K$ values mentioned above.

The above values of $K_{\mathrm{m}}^{\mathrm{app}}$. for PBG are similar to those for deaminase from human erythrocytes, $6 \mu \mathrm{M}$ at $\mathrm{pH} 8.2$ (Anderson \& Desnick, 1980), Rps. spheroides, 13-20 $\mu \mathrm{M}$ at pH 7.6 (Jordan \& Shemin, 1973), rat spleen, $1 \mu \mathrm{M}$ at pH 7.5 (Williams, 1984), but are significantly lower than those for algal enzymes; Euglena gracilis has a $K_{\mathrm{m}}$ value for PBG of $195 \mu \mathrm{M}$ at $\mathrm{pH} 8.0$ when operating in the absence of uroporphyrinogen III synthase (Battersby et al., 1979, 1983b) and Chlorella regularis gave values of 85-90 $\mu \mathrm{M}$ at pH 7.4 (Shioi et al., 1980).

The $N$-terminal amino acid sequence of $E$. coli $\mathrm{PBG}$ deaminase given in Table 3 represents the first amino acid sequence information to be published for any PBG deaminase. Preliminary results indicate that this sequence is very different from the $N$-terminal sequence for PBG deaminase from Euglena gracilis (G. J. Hart \& A. R. Battersby, unpublished work).

We thank Professor J. Fothergill and Mr. B. Dunbar of the Department of Biochemistry, University of Aberdeen, for the amino acid sequencing, Mrs. J. O'Brien for growing the cells, and the Science and Engineering Research Council for financial support.

\section{REFERENCES}

Anderson, P. M. \& Desnick, R. J. (1980) J. Biol. Chem. 255, 1993-1999

Battersby, A. R., Fookes, C. J. R., Matcham, G. W. J., McDonald, E. \& Gustafson-Potter, K. E. (1979) J. Chem. Soc. Chem. Commun. 316-319

Battersby, A. R., Fookes, C. J. R., Matcham, G. W. J. \& McDonald, E. (1980) Nature (London) 285, 17-21

Battersby, A. R., Fookes, C. J. R., Matcham, G. W. J., McDonald, E. \& Hollenstein, R. (1983a) J. Chem. Soc. Perkin Trans. I, 3031-3040

Battersby, A. R., Fookes, C. J. R., Hart, G., Matcham, G. W. J. \& Pandey, P. S. (1983b) J. Chem. Soc. Perkin Trans. I, 3041-3047

Berry, A. A., Jordan, P. M. \& Seehra, J. S. (1981) FEBS Lett. 129, 220-224

Cornish-Bowden, A. (1979) Fundamentals of Enzyme Kinetics, pp. 130-141, Butterworth and Co., London

Davies, R. C. \& Neuberger, A. (1973) Biochem. J. 133, 471-492

Hart, G. J., Leeper, F. J. \& Battersby, A. R. (1984) Biochem. J. 222, 93-102

Higuchi, M. \& Bogorad, L. (1975) Ann. N.Y. Acad. Sci. 244, 401-418

Jordan, P. M. \& Shemin, D. (1973) J. Biol. Chem. 248, 1019-1024

Shioi, Y., Nagamine, M., Kuraki, M. \& Sasa, T. (1980) Biochim. Biophys. Acta 616, 300-309

Weber, K., Pringle, J. R. \& Osborn, M. (1972) Methods Enzymol. 26, 3-27

Williams, D. C. (1984) Biochem. J. 217, 675-683

Williams, D. C., Morgan, G. S., McDonald, E. \& Battersby, A. R. (1981) Biochem. J. 193, 301-310 